\title{
Creating and Estimating Replacement in Evaluation Process through Multiple Criteria Decision Making
}

\author{
Veeresh Malagi ${ }^{1}$, Praveena Kumara K M ${ }^{2, *}$, Harish Babu G A ${ }^{3}$, Uday Kumar K $\mathbf{N}^{4}$ \\ ${ }^{I}$ Department of Mathematics, Jain University, Bengaluru, Karnataka, India \\ ${ }^{2,3,4}$ School of Applied Sciences, REVA University, Bengaluru, Karnataka, India.
}

ORCIDS: 0000-0002-4472-0718(Veeresh Malagi), 0000-0002-0969-8359 (Harish Babu)

0000-0001-8100-1395 (Praveen Kumara) 0000-0003-1412-7734 (Uday Kumar)

\begin{abstract}
:
Two major steps in the development of the life cycle of the system through analysis phase is to find the requirements by the user and to find solutions for the alternative systems meeting these requirements. Most of the research conducted in the phase is devoted to find the topic and to verify its importance. Evaluation process completely depends on how expert analyst judges in the domain. This paper proposes a multiple criteria decision making (MCDM) approach for Creating and Estimating Replacement when the user requirements are expressed in terms of certain operational measures such as time, price, risk, etc. These constraints form the basis for the user to make the necessary adjustments.
\end{abstract}

Keywords: Requirement analysis - Alternative generation Goal programming - Information system design.

\section{INTRODUCTION}

Without a framework to guide management and systems planners, the tendency is to serve the strongest manager or the greatest crisis. As a result, systems activities too often may move from crisis to crisis following no clear path, receiving only ex post facto justification. This tendency inflicts an unnecessary expense on the organization. Not only are costly computer resources wasted, but even more costly human resources are mismanaged. The cost of systems and programming personnel is generally twice that of the hardware involved in a typical project, and the ratio is growing larger as the cost of hardware drops and salaries rise. The need for such planning has been well documented (Anthony[1], Pyburn[14]). Davis has presented methodology is presented for eliciting enterprise information requirements and developing a long-range information architecture. The methodology is based on a combination of business system planning, critical success factors, and ends/means analysis. The methodology is independent of organizational structure, personnel, and hardware and software; and it has been successfully implemented in a variety of organizational settings. Dickson et al.[4] and Wetherbe et al.[16] has shown that methodologies such as BSP (IBM), critical success factors. Davis et al.[3] discuss several methodologies for determining system requirements and present a contingency approach for selecting a methodology based on specification uncertainty. Multi-criteria decision making (MCDM) procedures can be used whenever competing objectives have to be satisfied simultaneously and tested for sensitivity to changes. Such an approach has been used by Chandler et, all.[2] for evaluating information system designs. The process of formulating the plan is not well-defined in the information system literature. This article proposes a three-stage model for planning the Management Information System (MIS). The three stages are strategic MIS planning, organizational information requirements analysis, and resource allocation (Fazolallahi)[5]. Schniederjans M J [15] presented a book, this book reviews the knowledge on goal programming methodology and applications. The approach begins by finding differentiate goal programming from multi-objective decision making methodologist followed by GPM formulations strategies to address the methodological limitations and applications. The book concludes on future directions for goal programming methodologies and applications. Harish Babu et al. [7] presented a methodology which is a combination of man power supply model and Goal Programming with primitive Socio Economic goals. Harish Babu G A, et. All. [10] Proposed a model Goal Programming Approach to deferment of power generation in deregulated markets. Harish Babu et al. [8] developed a procedure to asses' availability making it faceable solutions to measure this concept for all patient by daily basis. The results obtained can be used in utilization screening to detect abnormal patterns of physician or hospitals. Harish Babu et al. [9] Provided the review of capital budgeting and nine mutual exclusive projects of large scale industry. The approach used here is goal programming as one of the alternative method. Harish Babu et al.[11] presented GP model for hospital administration. Harish Babu et al.[12] developed a goal programming model for allocation of human resources for hospital administration.

\section{DATA OF THE PROBLEM}

This work is conducted in a private company recognized globally located in Bangalore and study is done in a feasible way to automate the system in managing cash process.

The responsibility of managing investment related process is maintained by company's treasury department. The utility customers make payment at various banks which are dispersed in many districts and the deposits are transferred to 
International Journal of Engineering Research and Technology. ISSN 0974-3154, Volume 13, Number 9 (2020), pp. 2132-2136

(C) International Research Publication House. https://dx.doi.org/10.37624/IJERT/13.9.2020.2132-2136

the treasury day after. Then short term investments are decided based on the information on deposits and its transfers among banks who are members to main bank. During the study, the company got opportunities in cash management due to delay in payments and decisions taken regarding investments.

The main objective in the development of new system is to obtain accuracy in deposits w.r.t time so that opportunities in the investments can be accelerated. The management also expects to maximize the success in the project and minimize the project cost below the estimated cost in a year. Another objective is to automate the sub system of the district ledger.

The team formed to study the project has two clerks for operation, a cash manager, two graduates and a university professor. The starting system input is obtained through interview and feedback is obtained through diagrams presenting data flow.

The weekly meetings about the project is held initially and conducted monthly in later stages. The complete study happened in nine months and presented to the treasurer and two managers of the district.
Many application managers are consulted in later stages as there were no professionals involved in the team during initial stages of the study for the cost or parameter estimation.

An analysis of this system resulted within the identification of the subsequent six category among the Department of the Treasury that relate to the task of money management:

$$
\begin{array}{ll}
\text { i. } & \text { MR - Money Reporting Category, } \\
\text { ii. } & \text { TS - Transfer Selection Category } \\
\text { iii. } & \text { DT - Deposit Transfer Category, } \\
\text { iv. } & \text { WT - Wire Transfer Category } \\
\text { v. } & \text { BL - Bank Record Category } \\
\text { vi. } & \text { DR - District Record Category }
\end{array}
$$

The existing information shows that the contact between these category. Here we identified four objectives: time, price, risk and district record updating. The other designs of the six category were identified as: (current, i.e. manual; and altered,

\begin{tabular}{|c|c|c|c|}
\hline \multicolumn{4}{|c|}{ Priority $1: \mathrm{P} 1 \leq 3.5$ hours } \\
\hline CR-19.0/0.5 & TS- $-0.75 / 0.25$ & BL-1.50/0.5 & DT-1.25/0.75 \\
\hline \multicolumn{4}{|c|}{ Priority $1: \mathrm{P} 2 \leq 3.5$ hours } \\
\hline $\mathrm{CR}-19.0 / 0.5$ & $\mathrm{TS}-0.75 / 0.25$ & $\mathrm{BL}-1.50 / 0.5$ & WT -1.25 \\
\hline
\end{tabular}
i.e. automated). Thus, a total of $64\left(2^{6}\right)$ altered shapes were possible. Using the methodology delineate earlier, many style

\begin{tabular}{|c|c|c|c|c|c|c|c|c|c|c|}
\hline \multicolumn{5}{|c|}{ Growth money } & \multicolumn{6}{|c|}{ Process money } \\
\hline $\begin{array}{c}\text { Money } \\
\text { Limitations }\end{array}$ & Hardware & Software & Discussion & Connection & Preparation & $\begin{array}{c}\text { Statistics } \\
\text { Entry }\end{array}$ & Production & $\begin{array}{l}\text { Sub- } \\
\text { total }\end{array}$ & $\begin{array}{l}\text { Cut-rate } \\
\text { Operation } \\
\text { money }\end{array}$ & Total \\
\hline M1 & 49,000 & 5,000 & 0 & 7,000 & 10,000 & 0 & 100 & 100 & 379.1 & 71,379 \\
\hline M2 & 700 & 1,500 & 200 & 4,000 & 1,050 & 6,000 & 200 & 800 & 3032.8 & 10,483 \\
\hline M3 & 700 & 500 & 0 & 600 & 200 & 200 & 50 & 250 & 947.8 & 2,948 \\
\hline M4 & 700 & 700 & 200 & 1,000 & 200 & 200 & 50 & 250 & 947.8 & 3,748 \\
\hline M5 & 700 & 1,000 & 800 & 1,000 & 600 & 600 & 50 & 650 & 2464.2 & 6,564 \\
\hline M6 & 700 & 500 & 800 & 1,000 & 200 & 300 & 0 & 300 & 1137.3 & 4,337 \\
\hline MR-12 & 0 & 100 & 0 & 0 & 250 & 200 & 50 & 250 & 947.8 & 1,298 \\
\hline MR-16 & 0 & 100 & 0 & 0 & 250 & 200 & 50 & 250 & 947.8 & 1,298 \\
\hline MR-23 & 0 & 100 & 0 & 0 & 250 & 200 & 50 & 250 & 947.8 & 1,298 \\
\hline MR-24 & 0 & 100 & 0 & 0 & 250 & 200 & 50 & 250 & 947.8 & 1,298 \\
\hline MR-25 & 0 & 400 & 0 & 0 & 900 & 800 & 100 & 900 & 3411.9 & 4,712 \\
\hline
\end{tabular}
alternatives were generated for management thought. the specified data is given below.

Table 1: Method Arrangement

Table 2: Expected money Limitations in Rupees 
Table 3: Risk Assessment

\begin{tabular}{|l|c|c|c|c|c|c|c|}
\hline \multirow{2}{*}{ Measure } & \multicolumn{9}{|c|}{ Score of Success } \\
\cline { 2 - 9 } & Weight & CR & TS & DT & WT & BL & DR \\
\hline New hardware & $20 \%$ & 30 & 05 & 05 & 05 & 05 & 05 \\
\hline New software & $25 \%$ & 35 & 10 & 0 & 0 & 10 & 0 \\
\hline Familiarity of the similar systems & $20 \%$ & 50 & 20 & 20 & 20 & 20 & 20 \\
\hline Experience level of similar systems & $35 \%$ & 50 & 05 & 05 & 05 & 05 & 05 \\
\hline Total weighted score & & 42.25 & 9.25 & 6.75 & 6.75 & 9.25 & 6.75 \\
\hline
\end{tabular}

\section{GOAL PROGRAMMING MODEL:}

\section{Goal -1: "Satisfy Timeliness Requirement".}

The time-related goals immersed reducing the process times related to deposits and wire transfers to no quite three. 5 hours. The methods that have an effect on these goals and also the estimates of the time spent in every system on the trail below this and planned styles and shown in Table one. The time estimates below this system were provided by the Treasury Department and also the estimates below the automatic criteria were obtained from company systems personnel. The ensuing time goals are often expressed as follows:

$19 \mathrm{Y}_{11}+0.5 \mathrm{Y}_{12}+0.75 \mathrm{Y}_{21}+0.25 \mathrm{Y}_{22}+1.25 \mathrm{Y}_{31}+0.75 \mathrm{Y}_{32}+$ $1.5 \mathrm{Y}_{51}+0.50 \mathrm{Y}_{52} \leq 3.5$

$19 \mathrm{Y}_{11}+0.5 \mathrm{Y}_{12}+0.75 \mathrm{Y}_{21}+0.25 \mathrm{Y}_{22}+1.25 \mathrm{Y}_{41}+\mathrm{Y}_{42}+1.5$ $\mathrm{Y}_{51}+0.50 \mathrm{Y}_{52} \leq 3.5$

\section{Goal-2: "Minimization of Information System Price"}

This goal minimizes the price of changing the present day design of category to the brand new design. This fee includes the one time investment fee and the routine operating charges. The working price element included simplest the price of records access and output as they both bring about direct money expend. The value of strolling the pc (CPU prices), storage, and maintenance had been neglected because those were handled as fixed overhead by the employer and were no longer allocated to every person utility. Below a special value allocation scheme, some of these costs may be explicitly blanketed in the price expression.

Table 2 represents the value of changing the design of every subsystem to the new automated design and the price of its operation. The above charges had been expected underneath the idea that the design of all different category will continue to be unchanged. Further, the table also shows the possible value savings because of the overlapping use of sources with the aid of interacting category. The goal cost of improvement price changed into Rs. 50,000. The resulting fee expression is:

$71,379 \mathrm{Y}_{12}+10,483 \mathrm{Y}_{22}+2,948 \mathrm{Y}_{32}+3,748 \mathrm{Y}_{42}+6,564 \mathrm{Y}_{52}$ $+4,337 \mathrm{Y}_{62}-1,298 \mathrm{Y}_{12} \mathrm{Y}_{22}-1,298 \mathrm{Y}_{12} \mathrm{Y}_{62}-1,298 \mathrm{Y}_{22} \mathrm{Y}_{32}-$ $1,298 \mathrm{Y}_{22} \mathrm{Y}_{42}-4,712 \mathrm{Y}_{22} \mathrm{Y}_{52} \leq 50,000$.

\section{Goal-3: "Minimize Risk of Failure"}

The application improvement managers had been consulted to achieve the probability of failure of every category below automation. They evaluated the probability of failure by assigning ratings for every category in opposition to some of standards (see desk 3 ).

Using the standards weights assigned by them, the final chance of failure rating for each category changes calculated. Assuming that the threat of failure to stay below the present day layout is 0 , it is expressed as:

$42.25 \mathrm{Y}_{12}+9.25 \mathrm{Y}_{22}+6.75 \mathrm{Y}_{32}+6.75 \mathrm{Y}_{42}+9.25 \mathrm{Y}_{52}+$ $6.75 \mathrm{Y}_{62} \leq 0$.

\section{Goal-4: "Automate District Ledger Category"}

Management indicated a preference for programming the District record category (DR). But, this purpose is of low precedence and is pursued only in spite of different targets and desires are achieved to the credential desired. This goal is represented as:

$\mathrm{Y}_{62}=1$

\section{Structural Constraints}

Since only one strategy of each category can be applied, structural constraints had been introduced. As an example, the structural limitation for category 1 might be:

$$
\mathrm{Y}_{11}+\mathrm{Y}_{12}=1
$$

Similarly to these constraints, different translation constraints that convert the product expressions $\mathrm{Y}_{12} \mathrm{Y}_{22}, \mathrm{Y}_{12} \mathrm{Y}_{62}, \mathrm{Y}_{22} \mathrm{Y}_{32}$, $\mathrm{Y}_{22} \mathrm{Y}_{42}$, and $\mathrm{Y}_{22} \mathrm{Y}_{52}$ of the price balance to the suitable linearized variable $\mathrm{X}_{12,22}, \ldots \ldots \ldots, \mathrm{X}_{22,52}$ were also added to the model.

\section{Management Preference Structure}

The above goals and objectives are differing in nature. Enhancing the timeliness of the facts has a tendency to increase tool prices and might increase the probability of failure as more changes are added into the enterprise. To 
International Journal of Engineering Research and Technology. ISSN 0974-3154, Volume 13, Number 9 (2020), pp. $2132-2136$

(C) International Research Publication House. https://dx.doi.org/10.37624/IJERT/13.9.2020.2132-2136

create those adjustments, management furnished the subsequent choice structure:

\begin{tabular}{|l|l|}
\hline Priority & Goal \\
\hline $\mathrm{P}_{1}$. & Minimize development time deviation \\
\hline $\mathrm{P}_{2}$. & Minimize total price deviation \\
\hline $\mathrm{P}_{3}$. & $\begin{array}{l}\text { Minimize the over-all score representing the } \\
\text { probability of failure }\end{array}$ \\
\hline $\mathrm{P}_{4}$. & $\begin{array}{l}\text { Automate the category that updates the District } \\
\text { Record Category (DR) }\end{array}$ \\
\hline
\end{tabular}

\section{RESULT AND DISCUSSION}

This problem is solved using a software package called QSB + . The solution of the problem is as follows $\mathrm{P}_{1}$ controlled $\mathrm{P}_{2}$ and $\mathrm{P}_{3}$ controlled $\mathrm{P}_{4}$. Solution $\mathrm{P}_{3}$ is linked with least risk and price, however, for supplementary risk and price, $\mathrm{P}_{1}$ allows for the mechanization of category six as well. Note, however, that both the results $\mathrm{P}_{1}$ and $\mathrm{P}_{3}$ price 27,000 and 30,000 more than what was planned. If this supplementary prices is too big, the user may be run the problem again with a upper priority allotted to the price goals.

Table 4: Other Arrangement Plans and Their Success Levels

\begin{tabular}{|c|c|c|}
\hline $\begin{array}{l}\text { Structure } \\
\text { Selection }\end{array}$ & category to be Computerized & Goals / objectives Completed \\
\hline 1 & $\begin{array}{l}\text { Money Reporting Category (MR) } \\
\text { Bank Record Category (BL) } \\
\text { District Record Category (DR) }\end{array}$ & $\begin{array}{l}\text { Time goal achieved. } \\
\text { Price: underachieved (Rs.30,982) } \\
\text { Risk: underachieved( } 58.25) \\
\text { Mechanize DR - Yes }\end{array}$ \\
\hline 2 & $\begin{array}{l}\text { Money Reporting Category (MR) } \\
\text { Deposit Transfer Category (DT) } \\
\text { Bank Record Category (DR) }\end{array}$ & $\begin{array}{l}\text { Time goal achieved. } \\
\text { Price: underachieved (Rs.30,982) } \\
\text { Risk: underachieved( } 58.25) \\
\text { Mechanize DR - Yes }\end{array}$ \\
\hline 3 & $\begin{array}{l}\text { Money Reporting Category (MR) } \\
\text { Bank Record Category (BL) }\end{array}$ & $\begin{array}{l}\text { Time goal achieved. } \\
\text { Price: underachieved (Rs.27,943) } \\
\text { Risk: underachieved( } 51.50) \\
\text { Mechanize DR -No }\end{array}$ \\
\hline 4 & $\begin{array}{l}\text { Money Reporting Category (MR) } \\
\text { Transfer Selection Category (TS) }\end{array}$ & $\begin{array}{l}\text { Time goal achieved. } \\
\text { Price: underachieved (Rs.30,510) } \\
\text { Risk: underachieved( } 51.50) \\
\text { Mechanize DR -No }\end{array}$ \\
\hline
\end{tabular}

Additional other results can be made by way of specifying a more price of $Z$. Those opportunity answers allow for interchanges and reconsidering at the part of the user before popularity of a solution for execution. Also, many subjective elements that regularly can't be formulated mathematically within the version can be taken into consideration efficaciously at this stage in tapering down the person's desire to at least one opportunity.

On this unique case, the employer used different subjective statistics and decided on the opportunity $\mathrm{P}_{2}$, which called for the automation of category 1,3 and 5 . one of the foremost reasons for this desire become that the financial institution ledger machine was taken into consideration lots more crucial as it maintains bank balances which might be constantly converting because of transfers made amongst banks.

A actual-time protection of bank ledgers offers brief records on bank balances earlier than and after transfers. If this requirement become recognized earlier inside the investigative step, it may had been expressed as a constraint in the trouble. However, it isn't frequently possible for control to a priority country these terms. A method which include this may therefore enhance evaluation of options using records this is either subjective or tough to extract from the person inside the investigative point.

\section{REFERENCES}

[1] Anthony, R.N., "Planning and Central System, A Framework for Analysis", Harward Business School Press, Boston, 1965.

[2] Chandler, J.S., "A Multiple Criteria Approach for Evaluating Information Systems," MIS Quarterly, 6, 1 (March 1982), 61-74.

[3] Davis, G.B. and J.C. Wetherbe, "Developing a Long Range Information Architecture," Proceedings of National Computer Conference, Anaheim, CA, May 1983.

[4] Dickson, Gary and James Wetherbe, "Management of 
Information Systems”, McGraw Hill, New York, 1985.

[5] Fazolallahi, B., "A Framework for MIS Planning," School of Management, Syracuse University, Syracuse, NY, Ph.D. Dissertation, 1984.

[6] Framel, John, "Managing Information Cost and Technologies as Assets," Journal of Systems Management, (February 1990), 12-19.

[7] Harish Babu G A and Uday Kumar K N, "Aggregate Manpower Planning - A Goal Programming Approach"Pure and Applied Mathematics Journal, 4(6), (2015), $233-236$

[8] Harish Babu G A and Jayashree D N, "Optimal allocation of in-patent in acute care Hospitals" International Journal of Recent Scientific Research, Vol. 7(4), pp. 10272 - 10275, 2016.

[9] Harish Babu G A and Jayashree D, "Optimum allocation of resources in University Management through Goal Programming" Global Journal of Pure and Applied Mathematics, 12(4), N (2016), 2777-2784.

[10] Harish Babu G A, and Prveena kumara KM, "Deferment of Power Generation in Deregulated Markets - A Goal Programming Approach". International Journal of Mechanical Engineering and Technology, Vol. 9 (13), pp. 1091-1100, 2018.

[11] Harish Babu G A and Praveena Kumara K M, "A resource Allocation Model for Hospital Administration". International Journal of Engineering Research and Technology, NCERAME 2015 Conference Proceeding.

[12] Harish Babu G A and Praveena Kumara K M, and Uday Kumar K N, "Allocation of Human Resources in a Health Care Organization through Goal Programming", International Journal of Engineering Research and Technology, ISSN 0974-3154. Vol.11, pp. 51 - 63, 2018.

[13] Lee, S.M., "Goal Programming for Decision Analysis", Auerbach Publisher, Philadelphia, PA, 1972.

[14] Pyburn, P.J., "Linking the MIS Plan with Corporate Strategy: An Exploratory Study," MIS Quarterly, (June 1983).

[15] Schniederjans M J, "Goal Programming: Methodology and Applications". Kluwer Academic Publishers, Norwell, USA, 1995.

[16] Wetherbe, J. and G. Davis, "Strategic Planning Through Ends/Means Analysis," MIS Research Center, University of Minnesota, working paper, 1982. 